\title{
Barriers Of Early Diagnosis Of Breast Cancer: A Phenomenology Study Women In West Nusa Tenggara, Indonesia
}

\author{
Intan Gumilang Pratiwi, Baiq Yuni Fitri Hamidiyanti
}

\begin{abstract}
Objective on this research is to understanding barriers to early diagnosis Of Breast Cancer In West Nusa Tenggara Barat, Indonesia METHOD: In-depth qualitative interviews using grounded theory methods to identify themes, participants 20 women diagnosed cancer in West Nusa Tenggara Hospital.

Result: Women mentioned a variety of barriers, including their barriers including lack of knowledge and awareness of informants about the early symptoms of breast cancer, and second theme their behavior seeking non-medical treatment. The study found the most vulnerable age is 41-50 years old, that is $50 \%$ of all informants, the most informants level of education is junior high school $(40 \%)$, The most occupation is house wives which is $75 \%$ of all informant and $95 \%$ marital status informants is marriage. CONCLUSION: There are two barriers, lack of knowledge and awareness of informants about the early symptoms of breast cancer, and second theme their behavior seeking non-medical treatment.
\end{abstract}

Index Terms - barriers; cancer; breast; Indonesia.

\section{INTRODUCTION}

According to WHO states that in 2008 of 7.6 million deaths in the world that occurred due to disease, $13 \%$ of deaths were caused by cancer and 458 thousand cases of breast cancer. Nationally, cancer incidence has not been identified because there is no cancer registration that covers nationally, but from several cancer registration centers in Indonesia there are 23,310 cancer and breast cancer incidents as many as 2,743 patients [1], [2].

From preliminary study data conducted at the Darmais Cancer Hospital in Jakarta, it was found that in 2011 there were 10 types of cancer that most often occurred: breast cancer $43.7 \%$, cervical cancer $26.4 \%$, lung cancer $11.3 \%$, cancer nasopharynx $10,4 \%$, hepatoma $7.6 \%$, thyroid cancer $6.2 \%$, colon cancer $6 \%$, ovarian cancer $5.7 \%$, rectal cancer $5.6 \%$, and LMNH $3.5 \%$. This shows that breast cancer occurs more frequently than other cancer events [3].

Breast cancer is a common cancer in women and the second killer of all cancers in the UK. Breast cancer is a malignancy in breast tissue that can originate from the ductal epithelium or lobules. Breast cancer is one of the most common types of cancer in Indonesia. Based on Pathological Based Registration in Indonesia, KPD ranks

Published on July 16, 2020.

Intan Gumilang Pratiwi, Poltekkes Kemenkes Mataram, Indonesia. (corresponding e-mail: intangumil@ ${ }^{@}$ gmail.com).

Baiq Yuni Fitri Hamidiyanti, Poltekkes Kemenkes Mataram, Indonesia. (e-mail: baiqdiandanu86@gmail.com). first with a relative frequency of $18.6 \%$. (Data on Cancer in Indonesia in 2010, according to the Histopathology data of the Cancer Registration Board of the Indonesian Association of Pathology Specialists (IAPI) and the Indonesian Cancer Foundation [4]-[6].

It is estimated that the incidence in Indonesia is $12 / 100,000$ women, while in America it is around 92/100,000 women with a fairly high mortality of $27 / 100,000$ or $18 \%$ of deaths found in women. This disease can also be suffered in men with a frequency of about $1 \%$. In Indonesia, more than $80 \%$ of cases are found to be at an advanced stage, where treatment efforts are difficult. Therefore it is necessary to understand the efforts of prevention, early diagnosis, curative and palliative treatment as well as good rehabilitation efforts, so that services to patients can be carried out optimally. Cancer cases in West Nusa Tenggara from women aged 30-50 years in 2016 were 317,180 people, 14,431 people were examined and 61 cases of lumps / tumors were found [7], [8].

In this study we will understanding barriers to early diagnosis of Breast Cancer In West Nusa Tenggara Barat, Indonesia.

\section{MATERIALS AND METHOD}

This research used a qualitative method with phenomenology In-depth qualitative interviews using grounded theory methods to identify themes, participants 20 women diagnosed cancer in West Nusa Tenggara Hospital. The interview phase took place between August until October 2019. Sample recruitment for Interview phase, our Clinical teams in West Nusa Tenggara hospital trusts systematically identified eligible women from clinical records and recruited them to interviews conducted face to face. Eligible women were diagnosed breast cancer, over 17 years, Indonesian speaking, Can hear and speak clearly, and be able to participate in interviews.Data retrieval will be carried out until it reaches a saturasy point, once a meeting is held for 20-30 minutes for each informant.The researcher is assisted by the enumerator as a data collection tool, using the in-depth interview method.

\section{RESULT}

We interviewed 20 breast cancer patients, participants characteristics are explained in the Table I-V.

After repeatedly reading the results of interview transcripts and field notes from each informant, the researcher identified meaningful word quotations and 
statements related to the research phenomenon. Based on the research objectives, the main themes are as follows lack of knowledge and awarness of informants about the early symptoms of breast cancer and behavior seeking nonmedical treatment.

TABLE I: PARTICIPANTS CHARACTERISTICS BASED ON AGE

\begin{tabular}{cccc}
\hline & \multirow{2}{*}{ Age (Years) } & \multicolumn{2}{c}{ Percentage } \\
\cline { 2 - 4 } & $30-40$ & 3 & $\%$ \\
\hline 1 & $41-50$ & 10 & 15 \\
\hline 2 & $51-60$ & 6 & 50 \\
\hline 3 & $>60$ & 1 & 30 \\
\hline 4 & Total & 20 & 5 \\
\hline
\end{tabular}

TABLE II: PARTICIPANTS CHARACTERISTICS BASED ON LEVEL OF EDUCATION

\begin{tabular}{cccc}
\hline & \multirow{2}{*}{ Education Level } & \multicolumn{2}{c}{ Percentage } \\
\cline { 3 - 4 } & & $\mathrm{n}$ & $\%$ \\
\hline 1 & Elementary & 3 & 15 \\
\hline 2 & Junior High School & 8 & 40 \\
\hline 3 & Senior High School & 7 & 35 \\
\hline 4 & University & 2 & 10 \\
\hline & Total & 20 & 100 \\
\hline
\end{tabular}

TABLE III: PARTICIPANTS CHARACTERISTICS BASED ON EMPLOYMENT

\begin{tabular}{cccc}
\hline & \multirow{2}{*}{ Employment } & $\mathrm{n}$ & $\%$ \\
\cline { 3 - 4 } & Homemaker & 15 & 75 \\
\hline 1 & Entrepreneur & 1 & 5 \\
\hline 2 & Farmer & 2 & 10 \\
\hline 3 & Civil Servant & 2 & 10 \\
\hline 4 & Total & 20 & 100 \\
\hline
\end{tabular}

TABLE IV: PARTICIPANTS CHARACTERISTICS BASED ON MARITAL STATUS

\begin{tabular}{cccc}
\hline \multirow{2}{*}{ Marital Status } & $\mathrm{n}$ & Percentage \\
\cline { 3 - 4 } & Married & 19 & 90 \\
\hline 1 & Single & 1 & 10 \\
\hline 2 & Total & 20 & 100 \\
\hline
\end{tabular}

TABLE V: PARTICIPANTS CHARACTERISTICS BASED ON CANCER STADIUM

\begin{tabular}{cccc}
\hline \multirow{2}{*}{ Ca Stadium } & n & $\%$ \\
\cline { 2 - 4 } & & 7 & 35 \\
\hline 1 & II & 12 & 60 \\
\hline 2 & III & 1 & 5 \\
\hline 3 & IV & 20 & 100 \\
\hline & Total &
\end{tabular}

\section{DISCUSSIONS}

Based on the results of the interview the informant revealed the following:

Theme 1:

"There are about 2 weeks, it's been a long time, but I leave it because it doesn't hurt like that, then suddenly it continues to grow big and feels pain, then I go there and check into the health center" (IF1).

"I thought it was okay at first, I held it for a long time getting bigger and bigger, yeah like a chicken egg" (IF3).

"This is rather hard (pointing at the affected breast) for a long time but it does not hurt, there is a lump but it does not hurt, the medicine is requested by the shaman but does not work, continues to be left, we have not treated at all for a long time" (IF4).

"Well, if I don't know what year the lump has started, suddenly it's already big" (IF7).

"Eeee ... long ... maybe a few months, I leave it first, don't know it's called a tumor" (IF12).
"Sing paran lump biase wah (Sasak language mistaken for an ordinary lump) (IF14).

"No, I don't even feel that little mark because I don't feel sick, just as I recall, I felt itchy at night when I wanted to go to sleep, itchy, why I wasn't scratching, how long was it gone? After a while I took a shower I noticed how come there was a lump like that "(IF17).

"I let it go because I thought it was an ordinary lump" (IF18).

Theme 2:

Based on the results of the interview the informant revealed the following:

"Herbal remedy" (IF2).

"I only drink leaves and leaves of invitation" (IF3).

"U .. still, even though the treatment at the hospital I also drink like soursop leaves, etc." (IF6).

"No, just drink white turmeric ... that's the invitation" (IF9).

"Ee, if you go to the shaman often, but don't work, go to the shaman before you go to the doctor, you say this is a toy of all kinds" (IF11).

"Yes, I have but I have not recovered, I can't just go to the doctor" (IF12).

"Ever (went to a shaman)" (IF15).

"Yes to people who are smart at herbal things, so that they don't need surgery" (IF18).

Factors that inhibit breast cancer sufferers in conducting initial examination of this study are informants' knowledge and attitudes about the early symptoms of breast cancer, the informant is not aware of the initial symptoms such as lumps in the early signs of breast cancer. This is in line with the study of Dyanti et al in the study of the factors of delay in breast cancer sufferers in conducting preliminary examinations in health services in Bali that Most respondents who were diagnosed with advanced stages in this study in 2016 before conducting their first examination into health services had felt lump symptoms in the breast but ignored, because there is no pain in the breast, does not interfere with daily activities, and is considered not harmful to health. After the pain arises, the lump continues to enlarge, and several other symptoms occur in the breast, then respondents begin to think about doing a breast examination to a health facility, this is due to lack of knowledge about breast cancer [7].

This is in line with the study of Shanin Sayed et al in 2019 in rural areas in Kenya, as many as 442 women and 237 male heads of households participated in this survey. Although more than $80 \%$ of respondents have heard of breast cancer, less than $10 \%$ of women and male household heads are knowledgeable about 2 or more risk factors. More than $85 \%$ of men and women consider breast cancer as a very serious disease. More than $90 \%$ of respondents will visit a health facility for breast lumps. Introduction of signs of breast cancer, limited decision autonomy for women, preference for traditional healers, lack of trust in the health care system, inadequate access to services, limited early detection services that are obstacles to early breast cancer detection [7].

In this study also found the theme that the behavior of seeking informants are still looking for non-medical treatment (traditional), many of which after being diagnosed seeking treatment to herbalists or taking other herbs. This is also in line with research Jones et all in the UK In studies 
conducted in the UK many factors that become barriers to early detection of breast cancer include fear of diagnosing cancer, worry about time to see a doctor, prefer treatment alone rather than seeking treatment, focus to other things, do not know how to detect early, do not know where to go in seeking treatment, do not know about the importance of early diagnosis [6], [9], [10].

\section{CONCLUSION}

There are two barriers, lack of knowledge and awareness of informants about the early symptoms of breast cancer, and second theme their behavior seeking non-medical treatment.

\section{ACKNOWLEDGMENT}

The authors are thankful to Indonesian ministry of Health for funding this research

\section{REFERENCES}

[1] S. et. a. Panigoro, "Panduan Penatalaksanaan Kanker Payudara," Kementeri. Kesehat. Republik Indones. Kom. Penanggulangan Kanker Nasional., pp. 1, 12-4, 24-26, 45, 2008.

[2] N. K. Kardiyudiani, "Studi Fenomenologi; Harapan Pasien Kanker Payudara Yang Mendapat Kemoterapi Tentang Dukungan Keluarga Di Rumah Sakit Kanker Dharmais Jakarta," Thesis, 2012.

[3] M. Sihombing, A. N. Sapardin, B. Penelitian, and K. K. Ri, "Faktor Risiko Tumor Payudara Pada.....(Marice S, Aprildah Nur S)," Pus. Teknol. Terap. Kesehat. dan Epidemiol. Klin., vol. 5, no. 3, pp. 1-10, 2014.

[4] American Cancer Society, "Breast Cancer Early Detection and Diagnosis American Cancer Society Recommendations for the Early Detection of Breast Cancer," pp. 1-62, 2016.

[5] C. Kwok and F. K. Koo, "Participation in treatment decision-making among Chinese-Australian women with breast cancer," Support. Care Cancer, vol. 25, no. 3, pp. 957-963, 2017.

[6] R. A. Freedman et al., "Understanding Breast Cancer Knowledge and Barriers to Treatment Adherence: A Qualitative Study Among Breast Cancer Survivors," Biores. Open Access, vol. 6, no. 1, pp. 159-168, 2017.

[7] G. A. R. Dyanti and N. L. P. Suariyani, "Faktor-Faktor Keterlambatan Penderita Kanker Payudara Dalam Melakukan Pemeriksaan Awal Ke Pelayanan Kesehatan," J. Kesehat. Masy., vol. 11, no. 2, p. 276, 2016.

[8] E. W. Faida, "Analisa Pengaruh Faktor Usia, Status Pernikahan Dan Riwayat Keluarga Terhadap Pasien Kanker Payudara Di Rumah Sakit Onkologi Surabaya," J. Manaj. Kesehat. Yayasan RS.Dr. Soetomo, vol. 2, no. 1, p. 1, 2016.

[9] J. Wardle, K. Robb, S. Vernon, and J. Waller, "Screening for prevention and early diagnosis of cancer," Am. Psychol., vol. 70, no. 2, pp. 119-133, 2015.

[10] T. T. Donnelly and J. Hwang, "Breast Cancer Screening Interventions for Arabic Women: A Literature Review," J. Immigr. Minor. Heal., vol. 17 , no. 3, pp. 925-939, 2015 .

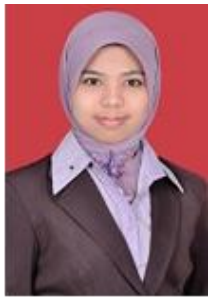

Intan Gumilang Pratiwi, is a lecturer by midwives profession and works at Midwifery Departement, Health Polytechnic Ministry of Mataram, West Nusa Tenggara, Indonesia and also Research Departement center. She is a Master of Midwifery. Intan has 3 years of practices as a midwife in hospital and 7 years as a lectures. She has also as journal manager, reviewer, and editor in various journal. She has some international publications about midwifery and health care.

Postal Address: Poltekkes Kemenkes Mataram, Jalan Praburangkasari, Sandubaya, Mataram, Nusa Tenggara Barat, Indonesia. Postal adress: 83232 